\title{
FACTORS AFFECTING MAMMALIAN ENCOUNTER RATES IN TRANSECT SURVEYS: A CASE STUDY IN ILHA GRANDE STATE PARK, STATE OF RIO DE JANEIRO, BRAZIL
}

\author{
Bruno Cascardo Pereira ${ }^{1}$, Atilla Colombo Ferreguetti ${ }^{2 *} \&$ Helena Godoy Bergallo $^{2}$ \\ ${ }^{I}$ Instituto Chico Mendes de Conservação da Biodiversidade (ICMBio). Parque Nacional Serra das Lontras, Ilhéus, BA, Brasil. CEP: \\ 45653-970 \\ ${ }^{2}$ Universidade do Estado do Rio de Janeiro (UERJ), Instituto de Biologia Roberto Alcantara Gomes, Departamento de Ecologia. Rua São \\ Francisco Xavier, 524, PHLC 220, Maracanã, Rio de Janeiro, RJ, Brasil. CEP: 20559-900 \\ E-mails: bruno.pereira@ibama.gov.br, atilla.ferreguetti@gmail.com,nena.bergallo@gmail.com
}

\begin{abstract}
Distance sampling is a widely used technique. However, the influence of several factors on the observations when using this technique, such as speed of the observers, microhabitat, weather, and method of detection, are still unknown. We aimed to evaluate the effect of various factors in the encounter rates and frequency of detection of mammalian species using the distance sampling technique with transects in an Atlantic Forest area, Ilha Grande, state of Rio de Janeiro, Brazil. We evaluated the effects of the forms of detection, sighting time, and the climate conditions on mammals samplings. Between December 2003 and May 2005, 128 transects were undertaken by a single observer, totalling $401.3 \mathrm{~km}$ and 382 hours. We recorded 163 individuals of nine species of mammals. Several factors affected our study using the distance sampling by linear transects, which include the animal activity period (i.e., object of study), followed by climate conditions, and transect location. We also found lower encounter rates in transects located in the north part of the island, because of the interference of tourists and the poaching pressure, which must be associated with the higher human densities in the north of the island that would inhibit the presence of certain species. This study highlights the importance of considering these variables when estimating mammal population sizes using distance sampling technique.
\end{abstract}

Keywords: Atlantic Forest; distance sampling; linear transects; poaching.

\section{INTRODUCTION}

Estimates of population size and density are fundamental to any effort of conservation of endangered species. These estimates provide basic support for several purposes related to conservation programs and political decisions, such as to evaluate habitat loss, to identify priority areas for conservation, to evaluate minimum viable populations, to determine the conservation status of a target species, among others. (e.g., Tomas et al. 2004, Cardillo et al. 2006, Cunha \& Loyola 2011, IUCN 2015, Buckland et al. 2016). However, long-term studies that monitor population sizes are rare for most taxa, including endangered species, especially in the Neotropics (Cardillo et al. 2006, Cunha \& Loyola 2011, IUCN 2015).

Among the many existing techniques to estimate density and population size (e.g., Capture-Mark-
Recapture methods; Seber 1986, Sutherland 2006), the distance sampling technique is one of the most frequently used (Buckland et al. 2001, 2004). This technique is based on the detection of animals along transects (e.g., linear transects; Buckland et al. 2001). This method is often used to assess populations of medium and large mammals in tropical forests (Peres 1999, Chiarello 2000, Gonzalez-Solis et al. 2002, Galetti et al. 2009, Desbiez et al. 2010, Gopalaswamy et al. 2012, Norris et al. 2012, Ferreguetti et al. 2015, 2016, 2017). The distance sampling is a simple and inexpensive method that can cover large areas in a short period of time (Cullen Jr. \& Valladares-Pádua 1997, Cullen Jr. \& Rudran 2004), with the assumption that target species can be directly observed and there are no misidentifications (Buckland et al. 2001). In the distance sampling technique, the main estimated parameter is the density of a population in a given study area. Furthermore, this method is also considered more 
accurate than methods that do not account for imperfect detection, even if the assumption that there are no errors in the distance measurements is violated (Buckland et al. 2001).

Distance sampling considers the imperfect detection of individuals of the target species during transect surveys (Mackenzie et al. 2006), considering that not all individuals are recorded. The individuals that are exactly on the transect line are recorded, so that the detection probability decreases as the object distance increases from the observer (Buckland et al. 2001, 2004). In general, distance sampling involves a series of models, which adjust detection functions for the observed distances, and uses these functions to estimate the proportion of objects missed during sampling (Buckland et al. 2001).

Despite being a technique widely used over the years, information on how different factors (i.e., speed of observers, microhabitat, weather, method of detection) influence observations while using distance sampling are still scarce. Mateos (2002) noted that altitude was the only variable that influenced the distribution of mammalian species in the Atlantic Forest. However, factors such as sighting time and speed of the observer had a quantitative effect on the encounter rate.

We aimed to evaluate the effect of various factors on the observations of mammalian species when conducting distance sampling technique using transects in an Atlantic Forest area. We tested how the way in which and when (sighting time) the study objects were detected affected the encounter rates of mammals. We also tested the effects of climate conditions (weather and wind) on the frequency of detections. We tested four hypotheses: (1) encounter rates will be higher for larger species during daytime observations, because it is easier to detect large individuals; (2) climatic conditions will negatively influence the detection of species, because individuals would avoid extreme weather conditions; (3) encounter rates will be higher in southern than northern parts of the island, because the northern side of the island is more densely populated; and (4) mid-sized mammals will be more abundant in less-disturbed areas in the island's south than in the north.

\section{MATERIAL AND METHODS}

Study area

Our study was carried out in the Ilha Grande State Park (PEIG hereafter) and in the Biological Reserve Praia do Sul (ReBio hereafter), in Ilha Grande island off the southwestern coast of Rio de Janeiro State, Brazil (Figure 1). PEIG is the second largest insular Biological park in Brazil and covers $120 \mathrm{~km}^{2}$, over half $(62 \%)$ of the island, which has $193 \mathrm{~km}^{2}$. ReBio covers an area of $35.02 \mathrm{~km}^{2}$ (INEA 2010). The climate is hot humid tropical without a dry season. Ilha Grande is the top of a submerged mountain and has two dominant types of topography, mountain and coastal plain (INEA 2010). Mountain peaks occur in the center of the island. Almost half of the area $(47 \%)$ is covered by dense, relatively pristine Atlantic rainforest. Disturbed forests, in an advanced successional stage, are the second major habitat type (43\%). The remaining areas comprise rocky outcrops with herbaceous vegetation (7\%), salt marshes, mangroves and beaches (2\%). Human settlements occupy $1 \%$ of the island (Alho et al. 2002) and is concentrated around the northern coastline of Ilha Grande Bay and in Abraão village. These areas are undergoing much anthropic disturbances due to tourism development, with new buildings, port facilities and expanding infrastructure (Alho et al. 2002).

\section{Sampling design}

During the period between December 2003 and May 2005, 128 transects were performed, totalling $401.3 \mathrm{~km}$ walked in 382 hours of effort. The transects were surveyed in five existing dirt trails in Ilha Grande in order to minimize the impact of opening new trails (Figure 1). Two of those trails were located in the northern part of the island, connecting Abraão Village to Palmas and Feiticeira beaches (respectively T01 and T02). The other three trails were on the south side of the island, connecting Dois Rios Village to Caxadaço and Parnaióca beaches, and to Jararaca locality (respectively T03, T04 and T05). Transects ranged in length from 2.1 
to $6.7 \mathrm{~km}$ (Table 1). All transects were marked at $50 \mathrm{~m}$ intervals. We recorded for each transect the evidence of poaching (e.g., hunting traps), and a Human density index (measured by the number of inhabitants in the nearest village divided by the distance to the nearest human settlement) to compare transects located in each region of Ilha Grande (north and south) (Table 1).
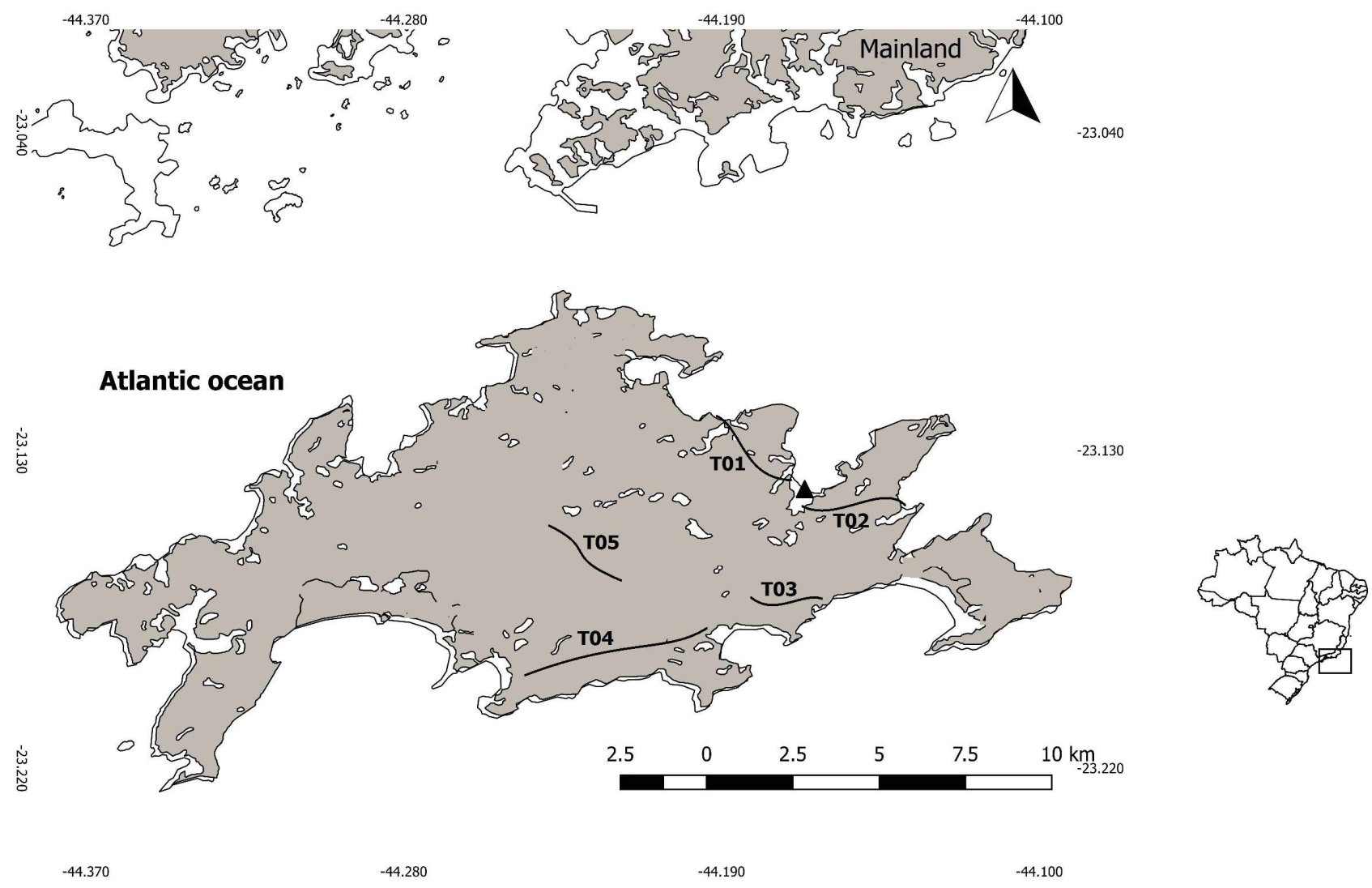

Figure 1. Transect locations (T01 to T05) of the mammal sampling in Ilha Grande, state of Rio de Janeiro, Brazil. The black triangle indicates the location of Abraão Village.

Table 1. Characteristics of transects, number of times each transect was walked ( $\mathrm{N}$ samples), total kilometers walked in Ilha Grande, state of Rio de Janeiro, Brazil.

\begin{tabular}{lcccccc}
\hline Transect & T01 & T02 & T03 & T04 & T05 & Total \\
\hline Extension (km) & 2.1 & 2.3 & 2.7 & 6.7 & 2.1 & 15.9 \\
N samples & 27 & 23 & 27 & 24 & 27 & 128 \\
Total Km walked & 56.7 & 52.9 & 72.9 & 160.8 & 56.7 & 401.3 \\
Island region & North & North & South & South & South & \\
Evidence of poaching & Yes & Yes & Yes & No & No & \\
Human density index & 405 & 412 & 444 & 134 & 103 & \\
Minimum altitude (m) & 0 & 10 & 10 & 0 & 20 & \\
Maximum altitude (m) & 190 & 160 & 170 & 170 & 250 & \\
Average altitude (m) & 125.1 & 106.3 & 106.4 & 81.3 & 136.9 & \\
\hline
\end{tabular}


Transects were walked by the observer during the activity time of the animals at dawn and twilight (Chiarello 2000). Transects were walked at an average speed of $1.1 \mathrm{~km} / \mathrm{h}( \pm 0.5)$, and under different climatic conditions divided into three categories by weather (clear sky, cloudy or rainy) and four categories of wind speed (no wind, weak, medium and strong). For each transect walked, the following information were recorded: sample size, number of transect, date, start time, end time, weather, and wind conditions.

The A/T (animal $x$ transect) perpendicular distance was measured considering the exact location where the animal was first detected. In the case of animals that used the tree layer, the distance was measured from the trunk of the tree where the animal was observed. When a group was observed, we considered the first animal detected in the group. Whenever an animal was observed, the following information was recorded: sighting time, species, A/ $\mathrm{T}$ distance, number of individuals (group size), location in the transect, and form of detection (visual or hearing). Hearing detections were registered by vocalizations (warning cries), noise caused by movements in the vertical strata (movements in twigs and branches), and noise caused by movements in the litter (movements on the ground). Visual detections were registered for animal movements without any associated noise and by the reflection of light from flashlights in their eyes at night. Sighting time was divided into six groups: group 1 (4:00 to 6:00 h), group 2 (06:01 to $08: 00 \mathrm{~h}$ ), group 3 (08:01 to 10:00 h), group 4 (16:00 to 18:00 h), group 5 (18:01 to 20:00 h) and group 6 (20:01 to 23:00 h).

We used the encounter rate as the dependent variable to evaluate the differences between the forms of detection and the sighting time of the mammalian species. Encounter rates were calculated using the number of individuals (or groups) by the total length walked in the transects, and were expressed as the number of individuals or groups every $10 \mathrm{~km}$ walked. We used the frequency of detection (i.e., which consists of presence and absence data, that is 1 for detected or 0 for not detected) of each species as the dependent variable to evaluate the effects of the climate conditions, because it was not possible to estimate encounter rates for each time that the transect was walked.

\section{Data analysis}

We assessed the relationship between the forms of detection on mammalian species encounter rates with a two-way analysis of variance (ANOVA) (forms of detection $\mathrm{x}$ species). When our models were significant we used Tukey post-hoc tests $(\alpha=$ $0.05)$ to compare means. We used Kruskal-Wallis test when the assumptions of normality and homoscedasticity were not met, which was the case of the sighting time of each species. We used a chisquare test to evaluate the effect of climate conditions on the frequencies of detection for the most frequent species using each time that the transect was walked. As there were cells with values below five, we used the Cochran correction in this analysis (Cochran 1977). All statistical analyses were performed in SYSTAT $11{ }^{\circledR}$ program.

\section{RESULTS}

We recorded 163 individuals of nine species of mammals in $382 \mathrm{~h}$ of observation: the common opossum Didelphis aurita (Wied-Neuwied, 1826) (Didelphimorphia, Didelphidae; $\mathrm{n}=21$ ), the ninebanded armadillo Dasypus novemcinctus Linnaeus, 1758 (Cingulata, Dasypodidae; $\mathrm{n}=13$ ), the brown howler monkey Alouatta guariba (Humboldt, 1812) (Primates, Atelidae; $\mathrm{n}=16$ ), the common marmoset Callithrix jacchus (Linnaeus, 1766) (Primates, Callitrichidae; $\mathrm{n}=25)$, the spotted paca Cuniculus paca (Linnaeus, 1766) (Rodentia, Cuniculidae; $\mathrm{n}=$ 35), the agouti Dasyprocta leporina (Linnaeus, 1758) (Rodentia, Dasyproctidae; $n=4$ ), the southeastern squirrel Guerlinguetus brasiliensis (Thomas, 1901) (Rodentia, Sciuridae; $\mathrm{n}=36$ ); the capybara Hydrochaeris hydrochaeris Linnaeus, 1766 (Rodentia, Caviidae; $\mathrm{n}=2$ ), and the orangespiny hairy dwarf porcupine Coendou spinosus (F. Cuvier, 1823) (Rodentia, Erethizontidae; $\mathrm{n}=10$ ). The number of species stabilized around an effort of $167 \mathrm{~h}$. The T04 transect was the only one where all nine species were observed. T01 and T02 
transects had the lowest richness, with only three species observed: D. aurita, G. brasiliensis, and C. jacchus (Table 2). The total average of mammal's encounter rate was 4.06 encounters every $10 \mathrm{~km}$ walked, and the highest encounter rate was for $G$. brasiliensis $(0.92$ encounters $/ 10 \mathrm{~km})$, followed by $C$. paca $(0.87$ encounters $/ 10 \mathrm{~km})$. The T05 transect presented the highest encounter rate (5.29 encounters $/ 10 \mathrm{~km}$; Table 2). Transects located on the south area (T03, T04 and T05) had higher richness than the northern area (T01 and T02). In T01 and T02, both located nearby Abraão Village, we only observed three species that were present in all transects (D. aurita, C. jacchus, and $G$. brasiliensis). During this study, tourists were found with some frequency in transects $\mathrm{T} 01$ and T02, and with less frequency in transects T03 and T04. No tourist was found in T05, since the access is prohibited. Signs of poaching were observed in transects T01, T02 and with less evidence in T03 and $\mathrm{T} 04$.

Eye reflection and movement were the two most frequent forms of detection, with eye reflection restricted to nocturnal species. Warning cries were mostly restricted to diurnal species such as $G$. brasiliensis and C. jacchus. Significant differences were found in encounter rates among the five forms of detection $(\mathrm{F}=3.432, \mathrm{p}=0.011)$ and among species $(\mathrm{F}=4.115, \mathrm{p}=0.009)$. The Tukey test $a$ posteriori indicated that there was a difference between detections by eye reflection and by movement on the ground, with higher encounter rates for the common opossum and for the spotted paca by eye reflection (Table 3).

Table 2. Encounter rates of each mammal species per transect in Ilha Grande, state of Rio de Janeiro, Brazil.

\begin{tabular}{lcccccc}
\hline Species & T01 & T02 & T03 & T04 & T05 & Total \\
\hline Alouatta guariba & 0 & 0.94 & 1.23 & 0.74 & 0.18 & 0.92 \\
Callithrix jacchus & 1.05 & 0.75 & 0.1 & 0.5 & 0.89 & 0.53 \\
Coendou spinosus & 0 & 0 & 0 & 0.06 & 0.18 & 0.05 \\
Cuniculus paca & 0 & 2.26 & 0.41 & 0.18 & 0.18 & 0.62 \\
Dasyprocta leporina & 0 & 0 & 0 & 0.5 & 0.89 & 0.33 \\
Dasypus novemcinctus & 0 & 0 & 0.14 & 0.37 & 1.58 & 0.39 \\
Didelphis aurita & 0.52 & 0 & 0.28 & 0.12 & 0 & 0.09 \\
Guerlinguetus brasiliensis & 1.76 & 0 & 0.41 & 1.62 & 1.06 & 0.87 \\
Hydrochoerus hydrochaeris & 0 & 0 & 0.41 & 0.31 & 0.35 & 0.25 \\
Total & 3.35 & 3.97 & 3.13 & 4.42 & 5.29 & 4.06 \\
\hline
\end{tabular}

Table 3. Total number of observations for each species according to the form of detection and significance level of the twoway ANOVA in Ilha Grande, state of Rio de Janeiro, Brazil.

\begin{tabular}{lccccc}
\hline Species & $\begin{array}{c}\text { Warning } \\
\text { cries }\end{array}$ & $\begin{array}{c}\text { Movement } \\
\text { in branches }\end{array}$ & $\begin{array}{c}\text { Movement } \\
\text { on the ground }\end{array}$ & $\begin{array}{c}\text { Motion } \\
\text { detection }\end{array}$ & $\begin{array}{c}\text { Eye } \\
\text { reflection }\end{array}$ \\
\hline Alouatta guariba & - & 6 & - & 10 & - \\
Callithrix jacchus & 10 & 9 & - & 6 & \\
Coendou spinosus & - & 3 & - & 2 & 5 \\
Cuniculus paca & 1 & - & 12 & 4 & 18 \\
Dasyprocta leporina & - & - & 4 & - & - \\
Dasypus novemcinctus & - & - & 5 & 2 & 6 \\
Didelphis aurita & - & 2 & 3 & 4 & 12 \\
Guerlinguetus brasiliensis & 11 & 10 & 5 & 11 & - \\
Hydrochoerus hydrochaeris & - & - & - & 2 & - \\
Total of observations & 22 & 30 & 29 & 41 & 41 \\
\hline
\end{tabular}


Only D. aurita and C. jacchus had their frequencies of detection affected by the weather, which were more detected under cloudy days $\left(\mathrm{X}^{2}=\right.$ 5.608, $\mathrm{p}=0.018$ and $\mathrm{X}^{2}=6.862, \mathrm{p}=0.008$; Table 4). Cuniculus paca was more detected in days with no wind and D. aurita in days of weak wind $\left(\mathrm{X}^{2}=\right.$ 4.154, $\mathrm{p}=0.042$ and $\mathrm{X}^{2}=17.757, \mathrm{p}=<0.001$; Table 4). Only two species were detected on days of strong wind: D. aurita and A. guariba. (Table 4).

In relation to the sighting time, the Kruskal Wallis test indicated the existence of significant differences between the encounter rates among the groups of sighting time $(\mathrm{KW}=11377, \mathrm{p}=0.044$;
Table 5). Most of the records were made between 06:01 to $08: 00 \mathrm{~h}$ (Tukey test a posteriori: $\mathrm{p}=0.03$ ) and between 18:01 to 20:00 h (Tukey test $a$ posteriori: $\mathrm{p}=0.04)$. Cuniculus paca was detected only after $16: 00 \mathrm{~h}$, and even then, only one out of 35 observations was before 18:00 h. Dasypus novemcinctus and $D$. aurita also presented crepuscular and nocturnal habits, but were also recorded in the period close to dawn. Primate species showed activity time between 06:00 and 18:00 h, and only one record of $A$. guariba occurred before $6: 00 \mathrm{~h}$. This case was a single individual found in the ground.

Table 4. Frequency of detection of each species and chi-square test results with $\mathrm{p}$ values according to different climate conditions. $\mathrm{df}=1$ for all the analyses in Ilha Grande, state of Rio de Janeiro, Brazil. Significant values for the chi-square test are in bold.

\begin{tabular}{|c|c|c|c|c|c|c|c|c|c|}
\hline \multirow[t]{2}{*}{ Species } & \multicolumn{3}{|c|}{ Weather } & \multicolumn{6}{|c|}{ Wind } \\
\hline & Clear & Cloudy & Rainy & $X^{2}(p)$ & $\begin{array}{c}\text { No } \\
\text { wind }\end{array}$ & Weak & Medium & Strong & $X^{2}(p)$ \\
\hline Alouatta guariba & 7 & 7 & 2 & $0.268(0.604)$ & 4 & 9 & 2 & 1 & $1.801(0.180)$ \\
\hline Callithrix jacchus & 9 & 15 & 1 & $6.862(0.008)$ & 8 & 15 & 2 & 0 & $0.198(0.656)$ \\
\hline Coendou spinosus & 4 & 5 & 1 & - & 5 & 4 & 1 & 0 & - \\
\hline Cuniculus paca & 19 & 14 & 2 & $1.294(0.255)$ & 25 & 6 & 4 & 0 & $4.154(0.042)$ \\
\hline Dasyprocta leporina & 1 & 2 & 1 & $0.001(0.982)$ & 3 & 0 & 1 & 0 & $2.77(0.096)$ \\
\hline Dasypus novemcinctus & 10 & 3 & 0 & $0.569(0.451)$ & 8 & 3 & 2 & 0 & $3.077(0.079)$ \\
\hline Didelphis aurita & 8 & 10 & 3 & $5.608(0.018)$ & 8 & 9 & 3 & 1 & $17.757(<0.001)$ \\
\hline Guerlinguetus brasiliensis & 16 & 19 & 2 & $6.862(0.008)$ & 12 & 18 & 7 & 0 & $0.198(0.656)$ \\
\hline Hydrochoerus hydrochaeris & 1 & 1 & 0 & - & 1 & 1 & 0 & 0 & - \\
\hline
\end{tabular}

Table 5. Number of observations for each species according to the sighting time and encounter rates (individual or group / $10 \mathrm{~km}$ ) in Ilha Grande, state of Rio de Janeiro, Brazil.

\begin{tabular}{|c|c|c|c|c|c|c|}
\hline Species & $\begin{array}{l}\text { o̊ } \\
\ddot{0} \\
\stackrel{1}{1} \\
\stackrel{8}{0} \\
\ddot{\dot{d}}\end{array}$ & $\begin{array}{l}\stackrel{8}{0} \\
\ddot{0} \\
\dot{0} \\
\frac{1}{0} \\
\ddot{0}\end{array}$ & $\begin{array}{c}\stackrel{8}{0} \\
\dot{\theta} \\
\underline{1} \\
\dot{0} \\
\ddot{0} \\
\stackrel{0}{0}\end{array}$ & $\begin{array}{l}\stackrel{8}{0} \\
\ddot{0} \\
\stackrel{1}{1} \\
\dot{\theta} \\
\ddot{0}\end{array}$ & $\begin{array}{l}\stackrel{8}{0} \\
\stackrel{\oplus}{0} \\
\stackrel{1}{0} \\
\ddot{\infty}\end{array}$ & 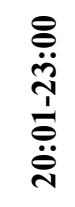 \\
\hline Alouatta guariba & 1 & 9 & 0 & 6 & 0 & 0 \\
\hline Callithrix jacchus & 0 & 16 & 5 & 4 & 0 & 0 \\
\hline Coendou spinosus & 2 & 1 & 0 & 0 & 4 & 3 \\
\hline Cuniculus paca & 0 & 0 & 0 & 1 & 18 & 16 \\
\hline Dasyprocta leporina & 0 & 1 & 3 & 0 & 0 & 0 \\
\hline Dasypus novemcinctus & 5 & 0 & 0 & 0 & 3 & 5 \\
\hline Didelphis aurita & 4 & 0 & 0 & 0 & 13 & 4 \\
\hline Guerlinguetus brasiliensis & 0 & 22 & 11 & 4 & 0 & 0 \\
\hline Hydrochoerus hydrochaeris & 0 & 0 & 1 & 1 & 0 & 0 \\
\hline Total of observations & 12 & 49 & 20 & 16 & 38 & 28 \\
\hline Encounter rate & 0.29 & 1.22 & 0.49 & 0.39 & 0.95 & 0.69 \\
\hline
\end{tabular}




\section{DISCUSSION}

The tree species present in all transects $(D$. aurita, C. jacchus, and G. brasiliensis) are considered as generalist or opportunistic species. Didelphis aurita is a generalist species (Cáceres 2003) as well as $C$. jacchus (Cunha 2005). Both are able to live in altered habitats and under the most different conditions, including near human habitations. In addition, $C$.jacchus is an invasive species introduced in southeastern Brazil (Cerqueira et al. 1998), and its presence has been reported in both urban and preserved forest areas. In Ilha Grande, we had higher encounter rates of $C$. jacchus in the northern area of the island (near Abraão Village). Guerlinguetus brasiliensis is an opportunistic species (Alvarenga \& Talamoni 2006), easily detected, with high encounter rates (Chiarello 2000, Marques 2004), and may occur in secondary forests, farms and parks (Emmons \& Feer 1997).

The lower encounter rates observed in $\mathrm{T} 01, \mathrm{~T} 02$, and T03 (south) when compared to T04 and T05 (north) may be due to human population densities, tourism, and poaching. Although considered an alternative for sustainable use in some protected areas, tourism can have an impact on habitat and natural populations (Rocha et al. 2012, Habibullah et al. 2016), and Ilha Grande receives a considerable amount of tourists throughout the year. The island has a network of trails that consists of 16 units used by tourists to reach the various parts of the island. However, since Abraão Village is the largest settlement in Ilha Grande (i.e., located in the north), where most of the hotels are located, the nearby trails are more frequently used by tourists. On the other hand, the southern trails are more isolated and less frequented. Despite a large portion of Ilha Grande is inserted in protected areas, such as the Ilha Grande State Park, poaching is also a common activity in the region. In fact, mammals species whose meat are much appreciated for food by the local people have become rare nearby the village, such as C. paca, D. leporina, and D. novemcinctus. Several studies have shown changes in the abundance of species, and even behavioural changes in some animals due to poaching pressure (Galetti et al. 2015, Ferreguetti et al. 2015, 2016, 2017). In fact, some species may become more skittish and difficult to see in environments where the practice of poaching is frequent (Peres \& Lake 2003, Ferreguetti et al. 2015, 2016, 2017). This may even affect their activity time, because some species tend to forage at night in areas with human presence (Cullen Jr. et al. 2001, Di Bitetti et al. 2008, Ferreguetti et al. 2015). Thus, the encounter rates could be lower in $\mathrm{T} 01$ and $\mathrm{T} 02$ transects because of the interference of tourists and the poaching pressure, which must be associated with the higher human densities in the north of the island, which would inhibit the presence of certain species.

The form of detection affected encounter rates. A higher detectability related to eye reflection and movement was expected, since eye reflection is restricted to nocturnal species, and the movement detection (visual) is facilitated for diurnal species. This may also explain the differences between the encounter rates depending on the time of observation. If we add up the six sighting time groups into two, day and night, night observations would have a higher number of records. Morgia et al. (2015) defend the benefits of distance sampling at night, mainly because the estimates generated in the analysis can be more precise and accurate, due to the easily detection of the animals by eye reflection. On the other hand, Duckworth (1998) mentions the difficulties in performing distance samplings at night, especially to detect more cryptic species, with weak eye reflection. In this study, the detection by eye reflection was very effective for nocturnal species. The night samplings in the south area provided data on species that occurred only or mostly in this period, such as $D$. novemcinctus and C. paca. Cuniculus paca is a highly poached species by the local population, so few observations were expected, but it was the second most sighted species and easily detected even over long distances by its intense eye reflection. On the other hand, the night samplings on the north side showed a low success of observations, where the only sighted species was $D$. aurita. According to Di Bitetti et al. (2008), some species change their behaviour when under poaching pressure because of the flashlights used by hunters, acquiring a "photophobia" and running away before being detected. This could explain the low frequency of observations or even the non-detection of certain 
species in the north transects. This supports the hypothesis that low species richness in the north area transects may be due to poaching pressure. On the other hand, on the southern area, where poaching is lower, hunted species were more frequently observed (C. paca, D. leporina, and D. novencimctus).

Although some authors avoid collecting data at night (Duckworth 1998, Marques 2004), this study has shown that they provide a good amount of data for species that are generally less frequently observed. Since most of the Neotropical mammals have predominantly nocturnal habits, a higher sampling effort during the night is required to obtain sufficient data to estimate the density of these species. Thus, we did not corroborate the hypothesis that the species are less detected at night samplings because of the limitation of the observer's view (i.e., limited by the flashlight range). All nocturnal species recorded here were mainly detected by the light reflection in their eyes, and were less dependent on motion or noise for detection. We observed that even species of small mammals, such as arboreal marsupials, could be detected at night by the eye shine.

Climate and wind also affected the frequency of detection, as expected. Peres (1999) does not recommend transects on rainy days because the weather would affect the ability of the observer to detect animals, both visually (i.e, animals tend to decrease their activity), and acoustically (i.e., difficulty in hearing noises caused by animal motion or alert). The same may apply in days of strong winds. The number of observations on rainy days was, as expected, much lower than on cloudy days, with few observations of A. guariba and D. agouti. Weather, however, did not affect the observation of nocturnal species, because it is possible to see the eye shine even under rain.

Several factors can affect the encounter rate estimates in studies using distance sampling by linear transects. In the present study, we detected the influence of animal activity period (i.e., object of study), followed by climate conditions, and transect location as important variables for estimating encounter rates in mammals. This study hopes to call attention of these variables when using this methodology widely applied in the study of mammals and to contribute to the experimental design of similar studies.

\section{ACKNOWLEDGEMENTS}

We thank the Centro de Estudo Ambientais e Desenvolvimento Sustentável (CEADS) and the Rio de Janeiro State University for the logistical support during the execution of this research. We also thank the Instituto Biomas for financial support. BCP is also grateful to Coordenação de Aperfeiçoamente de Pessoal de Nível Superior (CAPES) for a graduate scholarship.

\section{REFERENCES}

Alho, C. J. R., Schneider, M., \& Vasconcellos, L. A. 2002. Degree of threat to the biological diversity in the Ilha Grande State Park (RJ) and guidelines for conservation. Brazilian Journal of Biology, 62(3), 375-385.

Alvarenga, C. A., \& Talamoni, S. A. 2006. Foraging behaviour of the Brazilian squirrel Sciurus aestuans (Rodentia, Sciuridae). Acta Theriologica, 51(1), 69-74.

Buckland, S. T., Anderson, D. R., Burnham, K. P., Laake, J. L., Borchers, D. L., Thomas, L. 2001. Introduction to distance sampling: estimating abundance of biological populations. Oxford: Oxford University Press: p. 432.

Buckland, S. T., Anderson, D. R., Burnham, K. P., Laake, J. L., Borchers, D. L., Thomas, L. 2004. Advanced Distance Sampling: Estimating Abundance of Biological Populations. Oxford: Oxford University Press: p. 434.

Buckland, S. T., Rexstad, E., Thomas, L., Borchers, D. L. 2016. Distance sampling surveys of population size: enabling better decision-making by wildlife managers. In: S. T. Buckland (Ed.), UK Success stories in industrial mathematics. pp. 45-51. Springer International Publishing.

Cáceres, N. C. 2003. Use of the space by the opossum Didelphis aurita Wied-Newied (Mammalia, Marsupialia) in a mixed forest fragment of southern Brazil. Revista Brasileira de Zoologia, 20(2), 315-322.

Cardillo, M., Mace, G. M., Gittleman, J. L., Purvis, A. 2006. Latent extinction risk and future battlegrounds of mammal conservation. Proceedings of the National Academy of Sciences, 103(11), 4157-4161.

Cerqueira, R., Marroig, G., \& Pinder, L. 1998. Marmosets and liontamarins distribution (Callitrichidae, Primates) in Rio de Janeiro state, south-eastern Brazil. Mammalia, 62(2), 213-226.

Chiarello, A. G. 2000. Density and population size of mammals in remnants of Brazilian Atlantic forest. Conservation Biology, 14(6), 1649-1657.

Cochran, W. G. 1977. Sampling techniques. New York: John Wiley and Sons: p. 448.

Cullen Jr., L., \& Rudran, R. 2004. Transectos lineares na estimativa de densidade de mamíferos e aves de médio e grande porte. In: L. Cullen Jr., R. Rudran, \& C. Valladares-Pádua (Eds.), Métodos de estudos em biologia da conservação \& manejo da vida silvestre. pp. 169-179. Paraná: Editora UFPR.

Cullen Jr., L., \& Valladares-Pádua, C. 1997. Métodos para estudos de ecologia, manejo e conservação de primatas na natureza. In: C. Valladares-Pádua, R. Bodmer, \& L. Cullen Jr. (Eds.) Manejo e conservação da vida selvagem no Brasil. pp. 239269. Brasília: Sociedade Civil Mamirauá. 
Cullen Jr., L, Bodmer, E. R., \& Valladares-Padua, C. 2001. Ecological consequences of hunting in Atlantic forest patches, São Paulo, Brazil. Oryx, 35(2), 137-144.

Cunha, A. A. 2005. Estratificação vertical, abundância e tamanho populacional do macaco-prego (Cebus sp.) e do mico-estrela (Callithrix jacchus) no Maciço da Tijuca, Rio de Janeiro, RJ, Brazil. Departamento de Ecologia da Universidade Federal do Rio de Janeiro.

Cunha, F. M. A., \& Loyola, R. D. 2011. Spatial priorities for the conservation of threatened mammals in the Neotropics. Bioikos, 25(2), 75-90.

Desbiez, A. L. J., Bodmer, R. E., \& Tomas, W. M. 2010. Mammalian densities in a neotropical wetland subject to extreme climatic events. Biotropica, 42(3), 372-378.

Di Bitetti, M. S., Paviolo, A., Ferrari, C. A., De Angelo, C., Di Blanco, Y. 2008. Differential responses to hunting in two sympatric species of brocket deer (Mazama americana and M. nana). Biotropica, 40(5), 636-645.

Duckworth, J. W. 1998. The difficulty of estimating population densities of nocturnal forest mammals from transect counts of animals. Journal of Zoology, 246(4), 443-486.

Emmons, L. H., \& Feer, F. 1997. Neotropical Rainforest mammals: A Field Guide. Chicago: The University of Chicago Press: p. 396.

Ferreguetti, Á. C., Tomás, W. M., \& Bergallo, H. G. 2015. Density, occupancy, and activity pattern of two sympatric deer (Mazama) in the Atlantic Forest, Brazil. Journal of Mammalogy, 96(6), 1245-1254.

Ferreguetti, A. C., Tomas, W. M., \& Bergallo, H. G. 2016. Density and niche segregation of two armadillo species (Xenarthra: Dasypodidae) in the Vale Natural Reserve, Brazil. Mammalian Biology, 81(2), 138-145.

Ferreguetti, A. C., Tomas, W. M., \& Bergallo, H. G. 2017. Density, occupancy, and detectability of lowland tapirs, Tapirus terrestris, in Vale Natural Reserve, southeastern Brazil. Journal of Mammalogy, 98(1), 114-123.

Galetti, M., Giacomini, H. C., Bueno, R. S., Bernardo, C. S. S., Marques, R. M., Bovendorp, R. S., Steffler, C. E., Rubim, P., Gobbo, S. K., Donatti, C. I., Begotti, R. A., Meirelles, F., Nobre, R. A., Chiarello, A. G., Peres, C. A. 2009. Priority areas for the conservation of Atlantic forest large mammals. Biological Conservation, 142(6), 1229-1241.

Galetti, M., Bovendorp, R. S., \& Guevara, R. 2015. Defaunation of large mammals leads to an increase in seed predation in the Atlantic forests. Global Ecology and Conservation, 3, 824-830.

Gonzalez-Solis, J., Guix, J. C., Mateos, E., Lorens, L. 2002. Density estimates, group size, and habitat use of monkeys (mammals: Cebidae). In: E. Mateos, J. C. Guix, A. Serra, \& K. Pisciotta (Eds.), Censuses of vertebrates in a Brazilian Atlantic rainforest area: the paranapiacaba fragment. pp. 111-125. Barcelona: Universitat de Barcelona.

Gopalaswamy, A. M., Karanth, K. U., Kumar, N. S., Macdonald,
D. W. 2012. Estimating tropical forest ungulate densities from sign surveys using abundance models of occupancy. Animal Conservation, 15, 669-679.

Habibullah, M. S., Din, B. H., Chong, C. W., Radam, A. 2016. Tourism and biodiversity loss: implications for business sustainability. Procedia Economics and Finance, 35, 166-172.

INEA - Instituto Estadual do Ambiente. 2010. Parque Estadual da Ilha Grande (PEIG). http://www.ief.rj.gov.br/unidades/ parques/PEIG/conteudo.html Downloaded on 26 April 2016.

IUCN Red List of Threatened Species. Version 2015-4. www.iucnredlist.org Downloaded on 26 April 2016.

Mackenzie, D. I., Nichols, J., Royle, J., Pollock, K., Bailey, L., Hines, J. 2006. Occupancy estimation and modeling: inferring patterns and dynamics of species occurrence. Elsevier Publishing: p. 625.

Marques, R. M. 2004. Diagnóstico das populações de aves e mamíferos cinegéticos do Parque Estadual da Serra do Mar, SP, Brasil. Escola Superior de Agricultura "Luiz de Queiroz" da Universidade de São Paulo. p. 145.

Mateos, E. 2002. Global analysis of distance sampling counts results: effects of environmental and methodological variables. In: E. Mateos, J. C. Guix, A. Serra, \& K. Pisciotta (Eds.), Censuses of vertebrates in a Brazilian Atlantic rainforest area: the Paranapiacaba fragment. pp. 127-135. Barcelona: Universitat de Barcelona.

Morgia, V., Calmanti, R., Calabrese, A., Focardi, S. 2015. Costeffective nocturnal distance sampling for landscape monitoring of ungulate populations. European Journal of Wildlife Research, 61(2), 285-298.

Norris, D., Ramírez, J.M., Zacchi, C., Galetti, M. 2012. A survey of mid and large bodied mammals in Núcleo Caraguatatuba, Serra do Mar State Park, Brazil. Biota Neotropica, 12(2), 127-133.

Peres, C. A. 1999. General guidelines for standardizing linetransect surveys of tropical forest primates. Neotropical Primates, 7(1), 11-16.

Peres, C. A. \& Lake, I. R. 2003. Extent of nontimber resource extraction in tropical forests: accessibility to game vertebrates by hunters in the Amazon basin. Conservation Biology, 17(2), 521-535.

Rocha, E. C., Silva, E., Dalponte, J.C., Giúdice, G. 2012. Efeito das atividades de ecoturismo sobre a riqueza e a abundância de espécies de mamíferos de médio e grande porte na região do Cristalino, Mato Grosso, Brasil. Revista Árvore, 36(6), 1061-1072.

Seber, G. A. 1986. A review of estimating animal abundance. Biometrics, 267-292.

Sutherland, W. J. 2006. Ecological census techniques: a handbook. Cambridge: Cambridge University Press: p. 450.

Tomas, W. M., Rodrigues, F. H. G., \& Fusco, R. 2004. Técnicas de levantamento e monitoração de populações de carnívoros. Corumbá: EMBRAPA. 34p. 